\title{
石巻工場ミルワイドシステムの概要
}

\author{
日本製紙俰)石巻工場システム技術推進室 志 村 吉 彦

\section{Mill-Wide Computer System of Ishinomaki Mill} \\ Yoshihiko Shimura \\ Ishinomaki Mill, Nippon Paper Industries Co., Ltd.
}

\begin{abstract}
In Japan, several pulp and paper mills have been constructed each mill-wide computer system (total production management system) for recent ten years. But all fibrous materials contain moisture, and it is a delicate problem that the moisture content of paper is changed easily by circumstances. Furthemore, it is difficult to measure accurately moisture content of paper by on-line sensors. This is the reason systemizing of quantitative control is not easy in a pulp and paper industry to compare with the steel industry which has the similar process.

In our system, the production volume of paper is showed in area. The wed length equivalent to the area of paper on each process. Talking about a paper machine, the roll length on the reel part is measured automatically and strictly by counting pulse of the reel drum rotation. Using these reliable data from process and some data input by field operators manually, we can get the operating information and the loss quantity yielded in each process from papermaking to finishing.

The hardware with file servers and inteligent terminals are in a horizontal and distributed structure on a LAN. The phase II has been operated since this spring.
\end{abstract}

\section{1.はじめに}

10 数年程前に北欧の製紙工場を中心に始められた, コンピュータによる工場トータル管理システム(ミルワイ ドシステム) は，我が国でもいくつかの紙パルプ工場において，各社各様の構想のもとに取り組まれてきた。

ミルワイドシステムはLAN の発達により実用化が進んだが,この 10 年間でネットワーク技術はめざましい進 歩を遂げた。端末についても用途別の機種の開発が進み、ラップトップからワークステーションまでバラエティ に富んだものが提供されている。コンピュータテクノロジィが急激に発達したことにより，それを利用するユ一 ザーは現在大変恵まれた環境に置かれている。ミルワイドシステムについても新しい展開が期待される。

当社石巻工場では,この春から順次ミルワイドシステム第 2 期が稼㗢し始めた。今後の業界での新たなアプロー チに期待をこめて, 第 1 期稼值のものを含めてシステムの概要を紹介する。

2. 経

石巻工場は当社最大規模の工場である。パルプ設備は GP, TMP, NBKP, LBKP，新聞 DIP および色上DIP がある。それらのパルプが配合される 11 台の抄紙機は日産 $2,380 \mathrm{t}, 3$ 台のコーターは日産 $1,030 \mathrm{t}$ の生産能力が

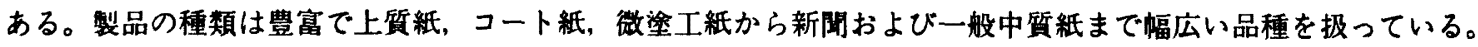

こうした大規模工場にミルワイドシステムを構築する上で，我々は特に骨格となるハードとネットワークの検 討に時間をかけた。いわゆる水平分散のシステムを考えていたが, 当時は実現可能なハードを有するメーカーは 限定されていた。結局, 強力なネットワークシステムを持つ東芝の事務用コンピュータ (DP シリーズ) が採用さ れた。

第 1 期ミルワイドシステムはマシンシステム, コーターラインシステム, 試験データシステム, 抄造実行計画 システム, 自動倉庫システム, 第 1 期ワインターシステムの各サブシステムから構成されている。導入経過の概 
略は次の通りである。

(1) 昭和 61 年 9 月：メーカー, 機種の決定 (東芝, DP シリーズ)

(2) 昭和 61 年 10 月：8 号マシン〜ワインダーラインでパイロットシステム稼働

(3) 昭和 63 年 9 月：本システム榢動開始

(4) 昭和 63 年 12 月：第 1 期システム完了

引き続き着手した第 2 期システムは, ワインターシステム (巻取刷込補助システムを含む), カッターシステ ム, 仕上システム, 倉庫システム, 計画 (加工明細) システムを各サブシステムから構成されている。導入経過 の概咯を次に示す。

(1) 平成元年 5 年：システム構策に着手

(2) 平成 2 年 8 月：ワインター，カッターの現業系のコンピュータとして新たに横河 YEWMACを採用

(3) 平成 3 年 11 月：仕上, 倉庫 (平判) システム稼働

(4) 平成 5 年 2 月: ワインターシステム稼動 (東芝, 横河)

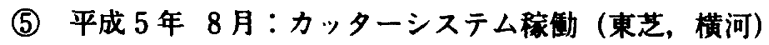

(6) 平成 5 年 9 月：第 2 期システム完了 (予定)

なおワインターシステムについては, 操作性の向上とリアルタイム処理の機能アップのため, 現業系として横 河電機の YEWMAC を接続し, 第 2 期システム開発の中で全面見直しを行った。第 2 期システムが立ち上がった ことにより,ママシンから入庫までのシステムの稼働が開始された。

\section{3. システム㔍成と基本的な考え万}

\section{1 基本成}

ネットワークの系としては東芝 DP シリーズのネットワーク, YEWMAC のバス, 計画システム用エンシニア リンクワークステーション(EWS)のバスがあるが, DPのものがミルワイドシステムの LANである。DPのネッ トワークは光ファイバーによるリンク状のケーフル (100 Mbps) と, 同軸のバス状のケーブル (10 Mbps) から 構成されている。ネットワーク管理についてはDPNET という強力なアプリケーションッールを持ち, 他ノード のデータを利用したり，相手ノードの端末としてソフトを使用したりすることが自由にできる。システムはホス トコンピュータによる集中管理ではなく，それぞれにインテリジェンスを持った現場端末（オぺレータワークス テーション) とファイルサーパー（セクションコンピュータ）をネットワークで接続し，そのデータを各所で自 由にアクセスできるようにした (図 1)。

ハード構成は次のようになっている。

$\mathrm{DP} 9070 \mathrm{E}$ 7(台)：セクションコンピュータ (A F F I )

DP $9060 \mathrm{E} 2$ : セクションコンピュータ（G：倉庫用, H：カッター部門管理用）

DP 9050 EX II $4:$ サフコンピュータ (仕上検查室)

DP 9040 EX 6:オペレータワークステーション (カッター用)

WPI $54:$ オペレータワークステーション (現場インテリシェット端末)

PIU $14:$ プロセスインターフェイスユニット（マシン，コーターのデータ収集用）

J 503010 : パソコン端末（事稀所用）

$\mathrm{J} 501070$ 台以上：一般端末，ラップトップ (事務所用)

YEWMAC は現業系のコンピュータとしてワインター, 巻取刷込補助 (パッキング)およびカッターの各シス テムで使用されている。機種としてはYEWMAC 520 とFA 500 を使用した。YEWMACはリアルタイムOS (YEWMAC 520 は 8 タスク) を有し，尃用のプロクラマフルコントローラであるFA 500 を同一バス (MLバス) 上に接続することができる(図2)。

YEWMAC 520 29：現業系コンピュータ（ワインター，巻取刷込補助（パッキンク），カッター）

FA 500 11: プロクラマブルコントローラ (ワインター, 巻取刷込補助 (パッキング), カッター) エンシニアリンクワークステーションは日本ユニシスのUS モデルファミリーを採用した。3台をイーサー ネットで接続している。ソフトは最新鋭のオブシェクト指向ッールである TIPPLER を使用した。TIPPLER は エキスパートのノウハウが誰でも自由に，しかもタイナミックに活用できるソフトであり，生産性が良くコスト 


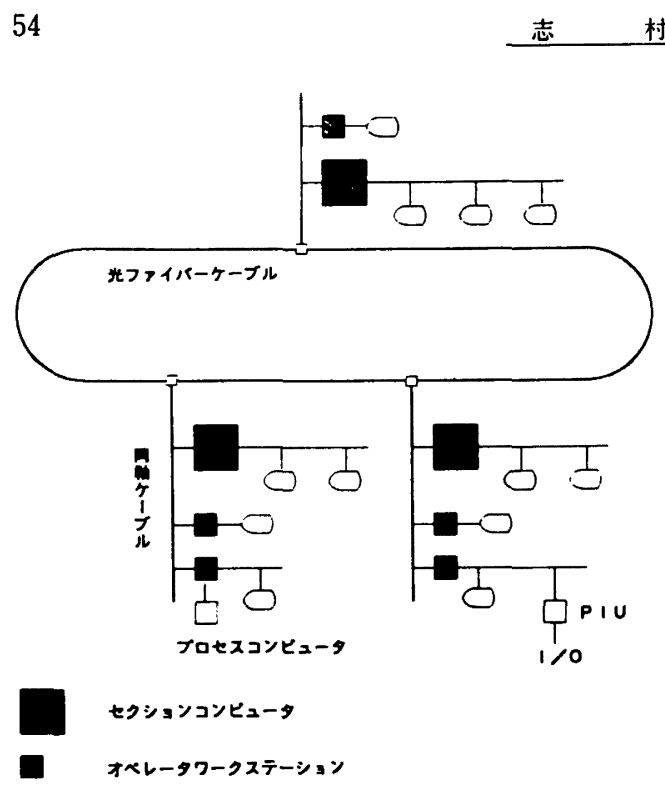

図 1 DP システム概念図

吉彦
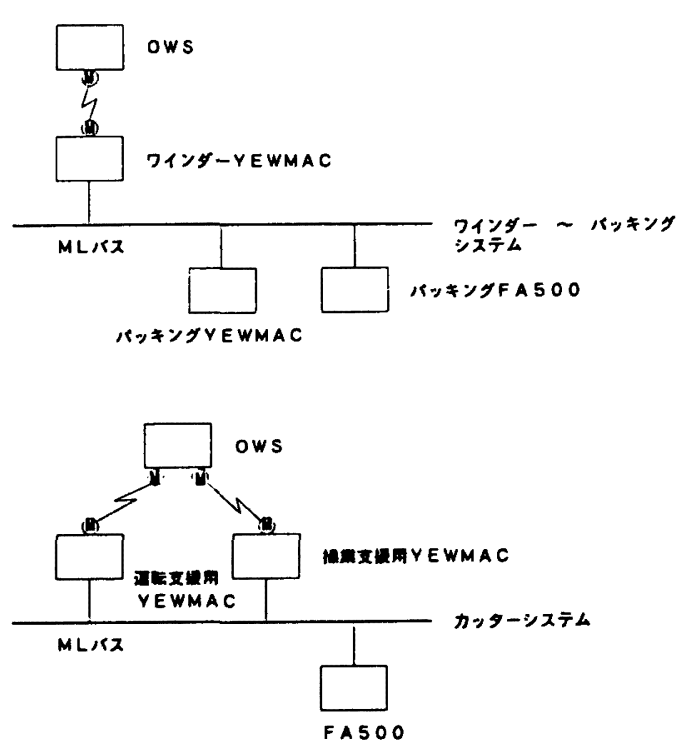

図 2 YEWMACシステム

パフォーマンスに優れたものである。開発工数は $\mathrm{C}$ 言語の 10 分の 1 と言われている。

US モデル $70 \mathrm{E} \quad 1$ : エンジニアリンクワークステーション (システム開発用)

US モデル $40 \mathrm{E} \quad 2$ : エンジニアリンクワークステーション（製品, 仕上用)

以上ネットワークの系統別にシステムの基本構成について述へてきたが, この他にミルワイドンステムをサ ポートする形でデータのやりとりをしているシステムが多数存在する。マシン, コーターのシステムでは坪量水 分計 (横河, アキュレイ)より坪量, 水分データを, ワインターでは欠陥管理システム (サンリツオートメイショ ン）より紙質欠陥の位置データを取り込んでいる。他に自動紙試験機（バルメット：ペーパーラボ）のデータの 取り込み，自動倉庫制御系システム(VAX) とのデータ通信なども行っている。

石巻工場のミルワイドシステムは，現場オペレータが使用するオぺレータワークステーションをべースとした ものである。データの収集方法はプロセス信号から時系列データを編集し，これに対してオぺレータが確定入力 を行いミルワイド情報を作成するという，オペレータへの依存度の高いシステムである。製造業における日本の オペレータの有能さは諸外国においても注目を集めているが, そのオペレータに様々な形で情報を提供し迅速な 对応を促すことをねらいとした，いわば日本型ともいえる新しい形態である。

\section{2 システムの權築方法}

ミルワイドシステムの開発は石巻工場システム技術推進室のメンバーが中心となって行った。現在人員は 17 名 であるか，第 1 期システムの開発では各現場よりキイマンとなる人を半年間専従させた。各サブシステム每にシ ステム室担当者, 現場担当者, メーカー (東芝) 担当者のクループを作り, フィールドの微底的な調查から始め てシステム概要設計書を作成した。第 2 期システム開発では現場の尃従者は臬かなかったか, 前回と同様の調査 を行い,さらにサブシステムとして沉用性の高いものをスペックとしてまとめることに力を注いだ。

色々な規模の, またそれぞれの事情を持った工場にミルワイドシステムを導入する場合，いくつかのパターン がとられている。石巻工場の場合は抄紙機のラインが多く，また全ラインにシステムを導入することを前提に考 えていたため, 沉用性を考虑したサブシステム単位の開発を行い横展開する方法を探用した。この方法を採るこ とによりコスト的にかなり安価に寨現することができた。

第 1 期システムの開発では 8 号マシン〜ワインターラインについて，メーカーの協力のもとにパイロットシス テムを作成し様々なテストを行った。ここで得られたノウハウは後の本システムの構策において大変役に立った。 石巻工場のミルワイドシステムはオペレータが行う確定入力により基本データの一部が作られるので, 事前の教 育やインストール後のフォローには特に気を配った。第 1 期だけでもマシン,コーターラインのオペレータ全員 
に行った事前教育の回数はトータルで 150 回にも及んだ。インストールについてはライン数が多いため急念され たが, システムが讵用性の高いものであることにより，大きなトラブルもなく順次短期間で立ち上げることがで きた。また, プロクラムの修正については，青梅工場と公衆回線を経由してハードを接続し迅速な対応を困った。

3.3 生産量とロス贯, ロス時間管理について

耗パルプ産業において，パルプや紙の重量をオンラインで正確に測定するということは大変むずかしいテーマ である。それはパルプや林は必ず水分を含んだ状態で存在し，しかもその水分量を測定するのがむずかしいこと に起因している。また䉻は周囲条件によって水分率が変動するので, 重量という単位では本来扱いづらいもので ある。取引上では紙は面積で报われており，製造工程においても本来それに準ずるべきであり，マシンやコーター ではある一定の愊に对する長さで管理することが妥当であろう。長さは重量に比へて非常に高い精度でデータが 得られ,オンライン計测が容易である。

我々はミルワイドシステムの構築を，マシンリールでの紙の巻長さを正確に測定し，オペレータの確定入力に よりロス区分毎のデータを収集することから始めた。各工程で発生するロスを色々な部署へ提示することにより ロスの量と発生简所を明確化し，それについて对策を講し管理することによって操業の効率を上げることが, 当 システムのねらいの1つである。

このロス量管理の考え方か， マシンからカッターまでのシステムの基本的なコンセプトである。マシンとコー ターではさらに時間的な要素も取り込まれており, 長さデータと合わせて操業の効率をリアルタイムで見ること ができるようになっている（図3，4）。

\section{4. 第 1 期システム}

4 章と 5 章では第 1 期と第 2 期のシステムについて具体的に述へることにする。

本章では第 1 期システムとして䡔筑されたものについて紹介する。

(1) マシンシステム

オペレータによる区間データの確定入力により, 直, 日, 銘柄の切れ目で編集される操業情報と, 枠替えの夕 イミンクで綟集されるスプール情報が作成される。操業情報は長さロス・時間ロス・効率といったマシン操業の 基本的なデータをリアルタイムに提供するので, 実操業に対して迅速なアクションをとることが可能である。ス プール情報は次工程に引き渡され，そこでデータの確認と歩留りの算出に利用される。

マシンの運転情報やリールでの生産塞績が人為的な操作を介さず算出され，それをもとに様々な解析を行うこ とができる。生産高を長さで計即し，高精度で信頼性の高い管理を実現している。

\begin{tabular}{|c|c|c|c|c|}
\hline . I & & & $E$ & \\
\hline$\pi$ & 枟 & 暗 & (1) & SD \\
\hline
\end{tabular}

\begin{tabular}{|c|c|c|c|c|}
\hline 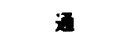 & 㫠 & $\boldsymbol{r}$ & \multicolumn{2}{|c|}{ 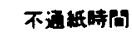 } \\
\hline \multirow{2}{*}{ 点昌可柣 } & 口 & $x$ & 雨 & 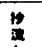 \\
\hline & 纽组斗 & 旺值内 & & 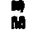 \\
\hline
\end{tabular}
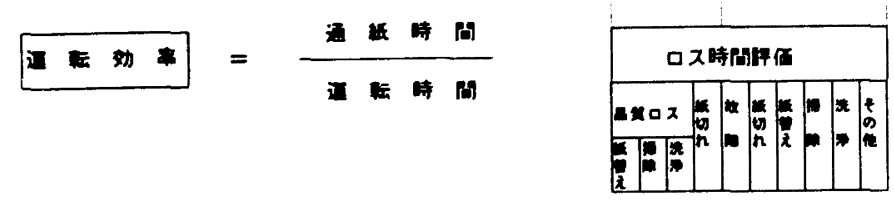

图 3 時間による操業の評価 


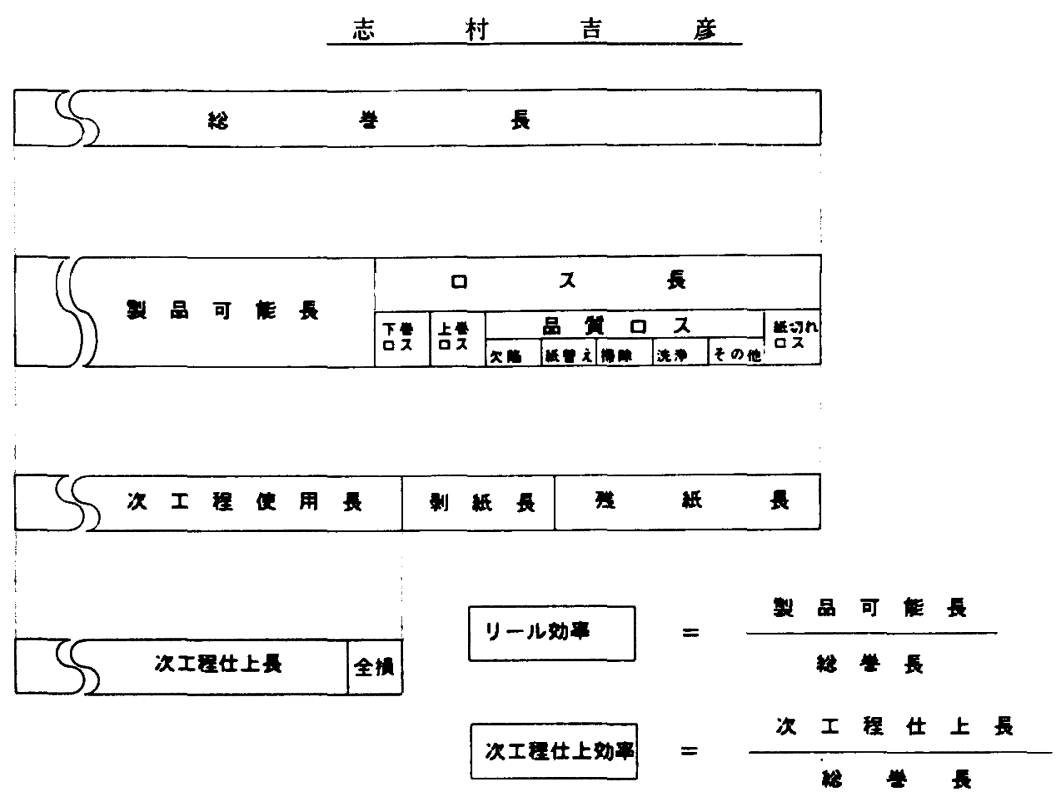

図 4 長さによる操業の評価

(2) コーターラインシステム

コーターについては, マシンと同様にリアルタイムのデータ管理を行い, 操業情報として長さロス・時間ロス・ 効率データを提供する。原紙の作りすぎ, さらに塗料の作りすきの無駄を管理し, 高品質の製品を生産するため のサポートを行う。レリーラ、スーパーについては時間についての評価は行わず長さのみについて管理する。

スプール情報については, 各工程でのスプール在庫を一括管理し, 使用スプールの履歴が追えるようになって いる。システムの骨格はマシンシステムに準拠した形になっている。

(3) 試験データシステム

マシンおよU゙コーターラインシステムでは, 劮替えあるいは取卸時にスプール 1 本分の操業データ, BM デー 夕，俩データが編集される。そのデータに対し，自動紙試験機および手分析データと調成の配合データを取り 込み，それを速報という形で表示し各所で利用することができる。

パルプについても，それぞれ定時分析時にデータが登録され各所で見ることができる。紙武験データとパルプ 試験データは，銘柄および月毎に統計処理が赛行され操業に利用されている。

(4) 抄造実行計画システム

本杜営業より発行される抄造明細書に基づき, マシンでの抄造高と抄順を決定する。抄造明細書のデータは本 社システムの工場分散コンピュータより, ミルワイドシステムに送信される。平判について, 仕上検查課か抄造 課に对し発行する断巻抄造依頼書もシステムでサポートされている。これらを各所で参照することができる。

(5) 自動倉庫システム

当工場 11 台目の $\mathrm{N} 5 \mathrm{M} / \mathrm{C}$ の稼働に合わせて，倉庫面積を確保するために平判立体倉庫が設置された。その データ管理を行うシステムとして構築されたものである。自動倉庫の入出庫管理は制御用のコンピュータが行っ ている。当システムは品名単位の在庫を管理するための情報処理システムである。入庫時のコンべア搬送中に, 制御系のオートフォーカスリーターからパーコードを読み込み当システムに通知する。出庫時は制御系に对して 当システムより指示を出力する。 

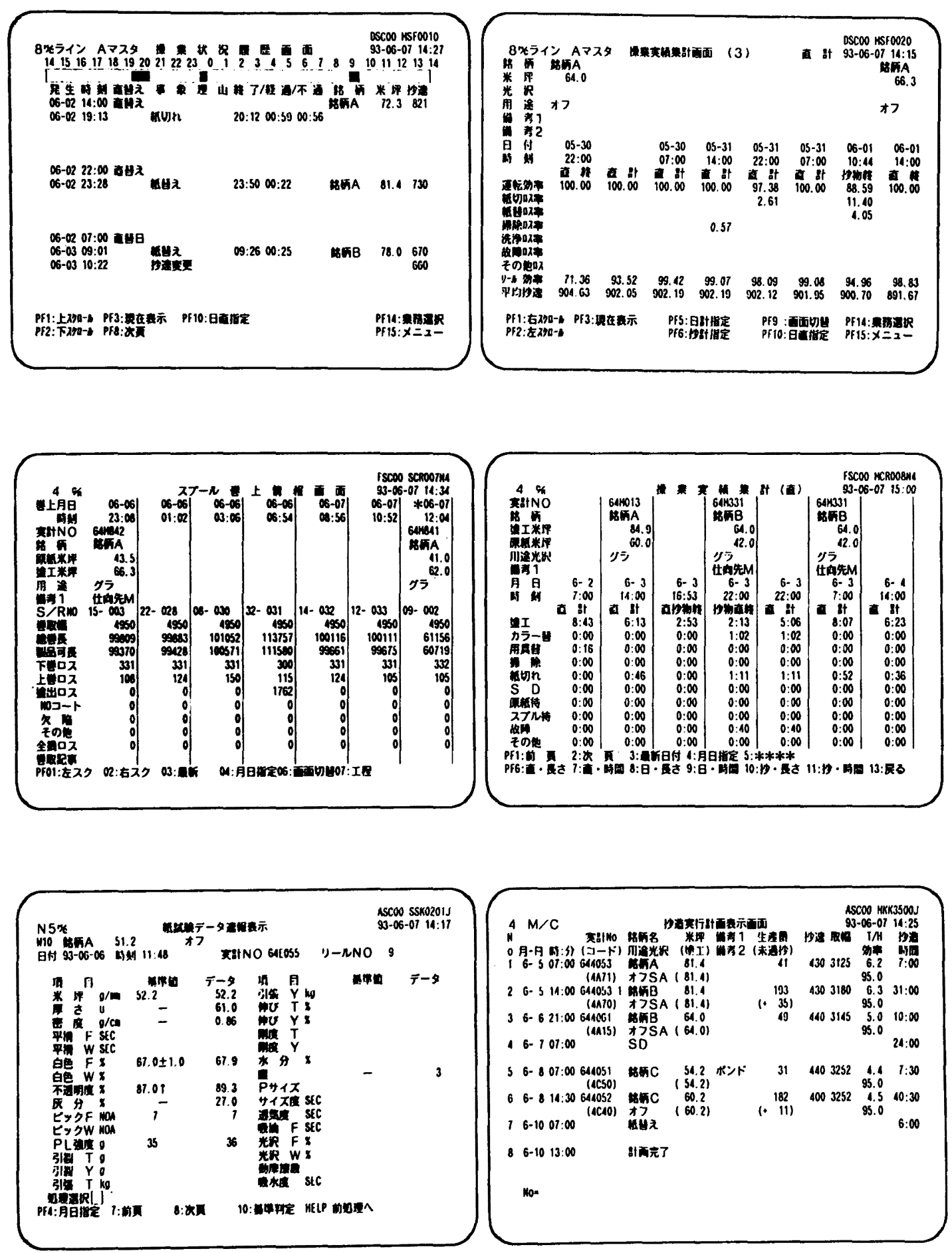


\section{5. 第 2 期システム}

本章では第 2 期システムとして構築されたものについて紹介する。

(1) ワインターシステム

オペレータ用のコンピュータを管理系と現業系に分離し, 後者のものはマルチタスクのプロセス用のコン ピュータを使用し，処理とレスポンスの向上を図っている。管理系のコンピュータではSF が作業計画を作成し， 現業系のコンピュータにタウンロードする。現業系では操業の流れの中でオペレータが格付入力を行う。そのデー タをミルワイドのネットワークを通じて各所で利用することができる。

またワインターでの処理を，取卸しデータ（長さを主とする）の作成と格付とに分けて，それぞれに対してワ インター効率と格付効率を定義した。操業を，処理したリールに対する仕上がりの面稓で評価できるようにした。

当システムは巻取刷込補助システムを含み, ワインターの格付情報をトラッキンクし，パッキンクマシン内で 鏡面自動刷込装置と胴面マーキンク装置にデータを出力できるようになっている。レッテルの自動発行は次フェ イズとした。

(2) カッターシステム

現業系のコンピュータがさらに操業支援用と運枟支援用に分離されている。運転支援側では，ワインターより

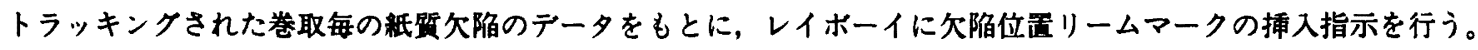
操業支援側ではオペレータが断裁山の確定を行う。その結果を断裁山毎に添付される選別票と，カッターの操業 日誌に相当する管理図として出力する。

現業系より管理系に操業実績と出荷実縝が送信され，ワインターと同様に直・日・作業単位で面稓による効率 評洒を行う。

断裁山の欠陥位直が明確になることにより，仕上選別工程の効率化に果たす役割が期待されている。

(3) 仕上システム

バーコード付きの山札をラヘルプリンターにより出カし，包装するとき添付されたものを読み込むことにより 包装実掼の計上を行う。抄造明細単位に実績がリアルタイムに編集され, 出荷ロット，包装形態毎の出来高が管 理できる。カッターシステムとの連結が次のフェイズで行われる予定である。そうすることにより未仕上高の管 理が可能になる。

(4) 倉庫システム

仕上システムで発行された山札のバーコードをリーターで読み込むことにより，平判製品の入庫情報が作成さ れる。入庫情報はリアルタイムで行われるため，台帳による在庫管理がなくなった。

(5) 計画 (加工明細) システム

本社で作成される抄造明細の内容をワインター，カッターの作業で使用し易くするために分解手直しを行う。 ハードはエンシニアリンクワークステーションを利用している。マルチウインドウの画面をマウスで操作しなが ら作成する。EWSのこれからの利用が期待される。 

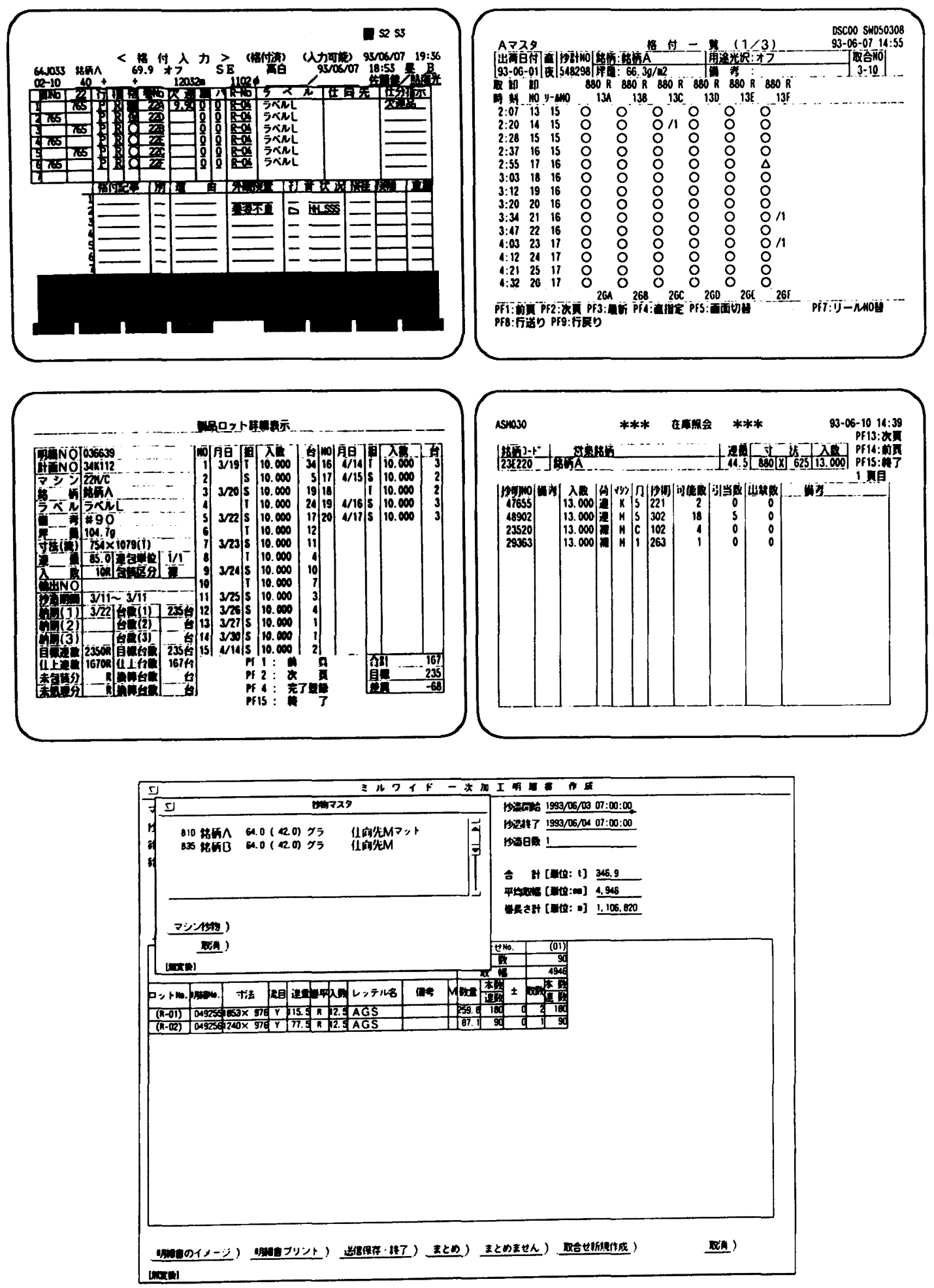


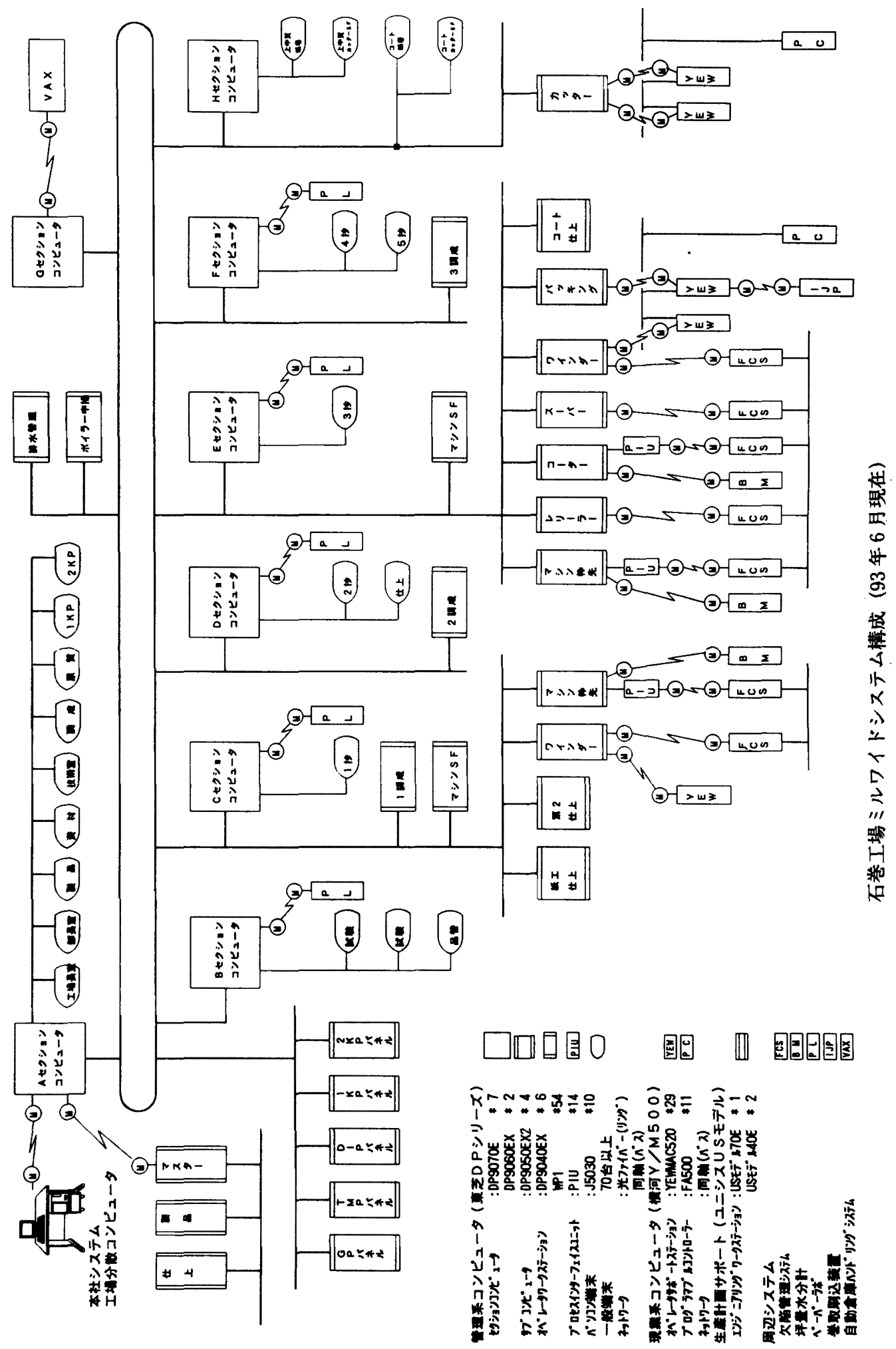




\section{6. ミルワイドシステムの効果と今後}

石巻工場のミルワイドシステムでは, リアルタイムに高精度で収集され, さらにオペレータによる確定入力が 付加された操業データを、ネットワークを通じ各所でいつでも見ることができる。紙パルプ産業のような 3 交替 制による連続操業を主体とする工場では，管理監督者は休日や夜間に操業現場に対して指示を出すことはできな い。このような状況下ではオペレータの業務として, 前後工程での生産状況や出来事を常に正確に把握し, 自工 程での操業に反映させていくことが要求される。そうしたことに利用できるデータを提供することがシステムの

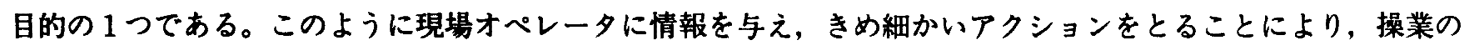
効率がらに向上することを期待している。

また，本システムを導入したことにより，今まで押さえることができず暧昧だったロス量を各工程毎に正確に 知ることができるようになった。ミルワイドシステムでは集計単位が細かく，直，抄造ロット単位でロスを管理 することができた。こうした詳細な信頼性の高いデータを用いて, 操業をきめ細かく評洒し管理していくことが, 改善のアクションを具体化する 1 つの条件である。

カッターシステムは稼微を開始したばかりであるが, 今回ミルワイドシステムのネットワークを通してマシン, コーターライン, ワインターで発生, あるいは処理した紙質欠陥の正確な位宣情報を,トラッキンクしてカッター に伝えることが可能となった。カッターシステムではその情報をもとに正確に欠陥りームを断裁山に㨂入するこ とができ, 選別工程に対して的確な情報を提供することができるようになった。カッターシステムの稼侸は, こ れからの仕上工程の効率化を推進する上で大きな力になると考えている。

石巻工場のミルワイドシステムは第 2 期システムが立ち上がったことにより, システムのインフラストラク チャーができあがった。しかし，複雑で取り扱いの厄介な紙パルププロセスの操業管理に役立てるためには，こ れで充分ということはなく，我々はさらなる努力を強いられている。現場オペレータと共に進めてきたシステム 構築の中で, 得られたノウハウと新たに提起された課題を整理して, システムのクレードを上げていくことを考 えなければならないであろう。

製品スペックの指示は本社の富士通システムより，工場の分散端末を通してミルワイドシステムに取り込み運 用している。但し, 出荷処理についてはまだ本社システムとはタイレクトに接続されていない。今後本社システ ムと融合を図っていかなければならない。また，石巻工場で開発したシステムはどのサブシステムも沉用性を重 視したものなので，様々な形で横展開することも可能であろう。

おわりに

ミルワイドシステムの棈策という仕事では，そのシステムの機能が工場の管理に直接係わるものなので，シス テムの理念つくりが非常にむずかしい。長い時間をかけて着実に穔み重ねていく党悟が必要である。

秖パルプ産業の将来を考えるに，このミルワイドシステムのような合理的なデータをもとに，操業効率の向上 や生販一体のシステム化を図ることが大切になってくるのではないだろうか。 